\title{
Ewa Banasiewicz-OssowsKa
}

\section{Żydzi wrocławscy w świadomości młodych mieszkańców Wrocławia - wiedza i stereotypy}

Streszczenie: Artykuł prezentuje wstępne wnioski z badań terenowych przeprowadzonych na terenie Wrocławia na przełomie czerwca i lipca 2019 r., dotyczących postrzegania Żydów wrocławskich przez młodych mieszkańców miasta. Badania miały na celu zweryfikować stan wiedzy na temat historii Żydów we Wrocławiu, ich współczesnej działalności społecznej, kulturalnej i religijnej oraz samej kultury żydowskiej. Ważnym ich aspektem było sprawdzenie, w jaki sposób społeczność ta funkcjonuje w świadomości młodych mieszkańców miasta, jakie jest oddziaływanie stereotypów na jej postrzeganie oraz jakie są źródła wiedzy na jej temat. Istotne było także określenie, które miejsca w przestrzeni identyfikowane są jako żydowskie oraz dowiedzenie się, czy młodzi mieszkańcy Wrocławia uczestniczą w wydarzeniach organizowanych przez społeczność żydowską, jak je oceniają i czy uważają je za potrzebne.

Słowa kluczowe: Żydzi we Wrocławiu, kultura żydowska, Dzielnica Czterech Wyznań, stereotyp Żyda, badania etnograficzne, edukacja międzykulturowa

\section{Wprowadzenie}

Historia społeczności żydowskiej we Wrocławiu sięga średniowiecza. Jej przedstawiciele zamieszkiwali miasto od XII do XV w., kiedy zostali z niego wygnani na około trzysta lat na mocy przywileju de non tolerandis Judaeis. Ponowne ukonstytuowanie się gminy żydowskiej nastąpiło w XVIII w. i przetrwała ona do wybuchu II wojny światowej. W tym czasie wrocławscy Żydzi stali się uczestnikami procesów, które zapoczątkowały istotne przemiany kulturowo-społeczne i religijne. Jak zauważył Ziątkowski (2000), to m.in. we Wrocławiu kształtowały się podwaliny oświecenia żydowskiego, to tutaj także formowały się podstawy nowych nurtów w judaizmie: judaizmu reformowanego i konserwatywnego. Był to również okres prężnego rozwoju samego miasta, w którym ważną rolę odegrali mieszkający tu Żydzi, uczestniczący w jego życiu gospodarczym, społecznym, kulturalnym i naukowym. Ślady 
ówczesnych żydowskich mieszkańców miasta i ich działalności odnaleźć można we współczesnym Wrocławiu, spacerując ulicami dawnej dzielnicy żydowskiej: Włodkowica, Krupniczą czy św. Antoniego; wokół wrocławskiego rynku, ulicą Świdnicką, czy odwiedzając żydowskie cmentarze.

Społeczność żydowską żyjącą we Wrocławiu po 1945 r. tworzyli zupełnie inni Żydzi, a odbudowana gmina żydowska nie posiadała żadnej ciągłości z gminą przedwojenną, ani w sensie personalnym, ani kulturowym (Ziątkowski, 2000). Koncepcja stworzenia na Dolnym Śląsku osiedla żydowskiego spowodowała napływ licznych grup Żydów, m.in. z terenów zajętych przez ZSRR. Na Dolnym Śląsku osiedliło się wówczas ok. 100 tys. Żydów, we Wrocławiu w lipcu 1946 r. było ich 17-20 tys. (Szaynok, 2006). Emigracje trwające przez cały okres powojenny, aż do wydarzeń marca 1968 r., spowodowały jednak, że życie żydowskie we Wrocławiu stopniowo zamierało (Banasiewicz-Ossowska, 2015). Jego ożywienie nastąpiło dopiero po 1989 r., po przemianach polityczno-społecznych. Pod koniec lat 90 . we wrocławskiej gminie żydowskiej zarejestrowanych było 220 osób, a cała społeczność we Wrocławiu miała liczyć ok. 150-200 rodzin. W 2002 r. na liście członków gminy znajdowało się 305 osób z Wrocławia, Legnicy i Żar (Waszkiewicz, 2010). Współcześnie, po wielowiekowej obecności Żydów w mieście, pozostała niewielka, licząca ok. 360 członków gmina żydowska (Włodarczyk i Kichler, 2016). Mimo niewielkiej liczebności również dziś społeczność ta stanowi jednak nieodłączny element życia społeczno-kulturowego miasta. Poprzez liczne działania Gminy Wyznaniowej Żydowskiej, Centrum Kultury i Edukacji Żydowskiej, przy współpracy z Fundacją Pro Arte, Fundacją Dzielnica Wzajemnego Szacunku Czterech Wyznań oraz wielu innych organizacji, podejmuje szereg inicjatyw, które mają na celu edukację międzykulturową i międzyreligijną. Temu służą organizowane koncerty, wykłady, warsztaty, wystawy czy Festiwal Kultury Żydowskiej „Simcha”. Wszystkie te inicjatywy są wydarzeniami otwartymi dla mieszkańców miasta i, jak się wydaje, budzą zainteresowanie zwłaszcza wśród młodych osób.

\section{Problematyka badań}

Celem artykułu jest przedstawienie wstępnych wniosków z badań empirycznych dotyczących postrzegania Żydów wrocławskich przez młodych mieszkańców miasta. Badania miały zweryfikować stan wiedzy na temat historii Żydów we Wrocławiu, ich współczesnej działalności społecznej, kulturalnej i religijnej oraz samej kultury żydowskiej. Ważnym ich aspektem było sprawdzenie, w jaki sposób społeczność ta funkcjonuje w świadomości młodych 
ludzi, skąd czerpią wiedzę na jej temat, a także jaki jest wpływ stereotypów na jej postrzeganie. Równie interesujące było stwierdzenie, czy młode osoby uczestniczą w wydarzeniach organizowanych przez społeczność żydowską, czy uważają je za potrzebne oraz które miejsca w przestrzeni identyfikowane są jako związane z Żydami.

Badania przeprowadzono we Wrocławiu w czerwcu i lipcu 2019 r., metodą wywiadów pogłębionych, ustrukturyzowanych kwestionariuszem. Rozmowy odbywano z osobami pełnoletnimi, we wszystkich kategoriach wiekowych, na potrzeby artykułu dokonano analizy 54 wywiadów z młodym pokoleniem mieszkańców miasta, między 18. a 35. rokiem życia, z osobami urodzonymi i mieszkającymi we Wrocławiu, a także mieszkającymi tu przynajmniej od pięciu lat ${ }^{1}$. Respondentami były zarówno osoby przypadkowe, jak i wcześniej umówione. Badania prowadzono wraz ze studentami etnologii i antropologii kulturowej Uniwersytetu Wrocławskiego i będą one kontynuowane w latach kolejnych w celach porównawczych.

Warto podkreślić, że w ostatnich latach podejmowano badania dotyczące postrzegania Żydów i polsko-żydowskiej historii oraz postaw wobec Żydów i Holokaustu wśród młodych osób, skupiano się jednak na grupie studentów (Łukaszewicz, 1983; Bartmiński, 1995) i młodzieży ze szkół ponadpodstawowych (Ambrosewicz-Jacobs, 2005; Wójcik, 2008; Bilewicz i Wójcik, 2009; Ambrosewicz-Jacobs, 2014; Szymański, 2012). Taki dobór grup wiekowych tylko częściowo pokrywa się z kryterium wieku przyjętym w artykule. Żadna ze znanych mi analiz nie odnosiła się też do będącej przedmiotem tego artykułu wiedzy na temat konkretnej, współczesnej, lokalnej społeczności żydowskiej i sposobu jej postrzegania.

\section{„Śladami wrocławskich Żydów”2 - wiedza o Żydach i żydowskich miejscach}

Niemal wszyscy respondenci zapytani o to, jakie mniejszości narodowe, etniczne i wyznaniowe zamieszkują Wrocław, podkreślali, że „Wrocław jest mieszan-

1 Rozmówcami były 32 kobiety i 22 mężczyzn, 18 osób z wykształceniem wyższym, 33 średnim, 26 w trakcie studiów wyższych, 3 nie udzieliły odpowiedzi na pytanie o wykształcenie. 24 osoby pochodziły z Wrocławia, 30 spoza miasta.

2 Tytuł odwołuje się do nazwy spacerów z przewodnikiem organizowanych cyklicznie we Wrocławiu - https://www.facebook.com/events/synagoga-pod-białym-bocianem-we-wrocławiu/śladami-wrocławskich-żydów-spacer-z-przewodnikiem/280 060589271389/ (26.03.2020). 
ką różnych kultur i wyznań" i byli świadomi obecności w mieście społeczności żydowskiej. Tak było w przypadku 51 osób. Wśród tych, którzy nie słyszeli o Żydach wrocławskich, były dwie osoby mieszkające w mieście od urodzenia i jedna mieszkająca tu od sześciu lat. Większość respondentów (42 osoby) potrafiła zlokalizować miejsca związane ze współczesną społecznością żydowską oraz ślady dawnego żydowskiego Wrocławia. Miejscem jednoznacznie kojarzonym z wrocławskimi Żydami i najczęściej wymienianym była Synagoga pod Białym Bocianem, wskazywano także na ul. Włodkowica ${ }^{3}$ i znajdujące się tu klubokawiarnie Ciż Cafe i Mleczarnię oraz cmentarze żydowskie: przy ul. Ślężnej i ul. Lotniczej. Wiele osób wskazało też dom Edyty Stein, w którym mieści się poświęcone jej muzeum, kilka wspomniało o domach handlowych Feniks i Renoma, pierwotnie należących do Żydów, oraz o nieistniejącej Nowej Synagodze. Trzy osoby słyszały także o kamieniach pamięci (Stolpersteinach), przypominających wymienionych z imienia i nazwiska Żydów, którzy zginęli podczas Holokaustu. Pojedyncze osoby wiedziały o istnieniu sali modlitewnej, budynku gminy żydowskiej, łaźni i koszernej stołówki, znajdujących się przy ul. Włodkowica, o dawnych szpitalach żydowskich przy ul. Wiśniowej i św. Antoniego, a także o Pasażu Pokoyhof ${ }^{4}$, iglicy na placu Solnym ${ }^{5}$ oraz o działających dziś we Wrocławiu żydowskich szkołach podstawowych. Część osób nie potrafiła jednak wskazać w przestrzeni miasta żadnych „żydowskich” miejsc, a niektóre wymieniały tylko te najbardziej znane: synagogę lub cmentarz.

Nieco ponad 35\% respondentów deklarowało, że zwiedzało Synagogę pod Białym Bocianem indywidualnie lub w towarzystwie znajomych. Najczęściej miało to miejsce przypadkiem, w czasie spacerów, ale również przy okazji Nocy Muzeów, wycieczki trasą „Śladami wrocławskich Żydów”, podczas koncertów muzyki żydowskiej czy jazzowych oraz debat panelowych organizowanych przez Dzielnicę Wzajemnego Szacunku. Tylko jedna osoba odwiedziła synagogę w ramach lekcji w szkole podstawowej. Warto zauważyć, że część respondentów wyrażała zdziwienie, że do synagogi mogą wejść osoby postronne, obawiano się także, że w czasie takiej wizyty wymagany jest jakiś określony strój. Rozmówcy pozytywnie oceniali jednak fakt, iż jest to miejsce, w którym odbywają się wydarzenia kulturalne i edukacyjne, podkreślając, że odróżnia je

3 Ulica uznawana za centrum żydowskiego życia. Znajdują się tu biuro gminy żydowskiej, koszerna stołówka, Synagoga pod Białym Bocianem, szul i mykwa.

4 Znajdowały się tu: bożnice Bialska, Leszczyńska oraz do 1911 r. Synagoga Krajowa.

5 Według jednej z interpretacji płomień nawiązuje do spalenia w tym miejscu Żydów w 1453 r. 
to od kościołów katolickich. Synagogę uznali za ważny obiekt na mapie miasta, stanowiący atrakcję turystyczną nie tylko ze względu na organizowane wydarzenia, ale również walory architektoniczne. Określali ją jako miejsce administracyjne, ośrodek duchowy i społeczny, żydowską świątynię, miejsce modlitwy i zgromadzeń, w którym odbywają się, jak sądzono, święta, śluby, wesela i lekcje religii dla dzieci. Jeden z mężczyzn, który uczestniczył w projekcie organizowanym przez Dzielnicę Czterech Wyznań, zauważył także, iż „swoje religijne zadanie spełnia wyłącznie wtedy, kiedy znajduje się w niej Tora" (38)

Za współczesne centrum żydowskiego życia uznano ul. Włodkowica i okolice synagogi, stanowiące swego rodzaju „ulicę żydowską" czy też, jak określił rozmówca: „małą dzielnicę żydowską, taką umowną" (6), która w świadomości wielu utożsamiana jest z Dzielnicą Czterech Wyznań. O istnieniu Dzielnicy wiedziała większość rozmówców (42 osoby), wskazując w pewnym przybliżeniu jej lokalizację. Nie wszyscy potrafili jednak poprawnie wymienić wyznania wchodzące w jej skład, zamiast wyznania ewangelickiego podając najczęściej islam. O idei Dzielnicy wypowiadano się bardzo pozytywnie, chwaląc jej antydyskryminacyjne i międzykulturowe działania: „To bardzo fajna inicjatywa, aż dziw, że udało się stworzyć coś takiego, uświadamiają o tym, że można żyć obok siebie w zgodzie" (27). Respondenci deklarowali, że polecają to miejsce znajomym jako atrakcję turystyczną, ponieważ „to jest takie niespotykane, że cztery wyznania są w tak niewielkiej odległości od siebie" (34).

Wiele osób przyznało, że często bywa w okolicy Dzielnicy Czterech Wyznań, ul. Włodkowica i synagogi, odwiedzając znajdujące się tu restauracje i kawiarnie, które wybierają ze względu na ich specyficzną atmosferę. Włodkowica i dziedziniec synagogi określano jako miejsca odizolowane od ścisłego centrum, ładnie odrestaurowane i spokojne. Według informatorów: „Na Włodkowica czuje się taką inność, taką pozytywną inność, estetyka jest inna niż na pozostałych ulicach wrocławskich” (6), „dzielnica ma swój klimat, historię, nawet muzykę, można tam spotkać ludzi ubranych w specyficzne stroje" (4), „tym, co wyróżnia tę część miasta są instytucje żydowskie, są one na swój sposób specjalne” (49), „dzielnica robi wrażenie, jest tam sporo miejsc, które mają swoją historię, nabrały jakiegoś znaczenia, a także obrosły swego rodzaju legendą" (50). Pojawiły się także przeciwne opinie, sugerujące, że ta część miasta nie wyróżnia się niczym i nie kojarzy się z Żydami, co może świadczyć o tym, że w świadomości części młodych osób ul. Włodkowica funkcjonuje jednak w zupełnym oderwaniu od jej żydowskiej przeszłości i teraźniejszości.

6 W nawiasach podano numery wywiadów. 
Młodzi ludzie w zdecydowanej większości nie znają historii wrocławskich Żydów, nie wiedzą, gdzie znajdowała się średniowieczna dzielnica żydowska ani w jakich okolicznościach pojawili się tu po wojnie Żydzi polscy. Do wyjątków należały osoby, które z racji wykształcenia potrafiły przytoczyć niektóre fakty z ich dziejów, wspominając m.in. o macewie Dawida, syna Sar Szaloma, roli inkwizytora Jana Kapistrana w prześladowaniach, zakazie osiedlania się w mieście czy o Nocy Kryształowej. Większość respondentów nie była też świadoma istnienia współcześnie gminy żydowskiej we Wrocławiu i nie wiedziała, na czym polega jej działalność. Osoby, które potrafiły ją opisać, zwracały uwagę na to, iż gmina pełni funkcje reprezentacyjne, integruje, odbudowuje mniejszość żydowską, promuje jej kulturę, opiekuje się zabytkami, ale też wydaje posiłki, organizuje obrzędy, modlitwy oraz wykłady edukacyjne. Niewielu respondentów umiało także poprawnie odpowiedzieć na pytanie o to, kim jest rabin i jaka jest jego rola w społeczności żydowskiej. Z reguły utożsamiano go z księdzem w Kościele katolickim, proboszczem, a nawet z „kimś w rodzaju papieża”, jedna z osób stwierdziła też, że jest „jak nasz prezydent” (7). Zdarzały się też jednak prawidłowe odpowiedzi: „nie jest odpowiednikiem księdza, jest jakby urzędnikiem, ale jednocześnie duchownym” (31), „to przewodnik duchowy, nauczyciel, mentor, zajmuje się przewodzeniem społeczności, łączy to, co święte, z tym, co świeckie” (23), „jest odpowiedzialny za interpretację Tory i inaczej niż księża, może mieć dzieci i żonę" (4).

Wielu rozmówców nie potrafiło też wskazać żadnej osoby wywodzącej się ze współczesnego środowiska Żydów wrocławskich. Uczyniło to tylko pięciu respondentów, wymieniając Jerzego Kichlera, którego określono jako osobę odpowiedzialną za ponowne uruchomienie gminy żydowskiej i synagogi, aktualnego rabina Davida Basoka, byłego przewodniczącego gminy Aleksandra Gleichgewichta oraz Bente Kahan, pieśniarkę i założycielkę Fundacji. Kilku badanych odwołało się też do postaci historycznych: m.in. Edyty Stein ${ }^{7}, \mathrm{Lu}-$ dwika Hirszfelda ${ }^{8}$, rodziny Wertheimów ${ }^{9}$ czy braci Barasch ${ }^{10}$.

Jednym z ważniejszych wydarzeń skierowanych do mieszkańców Wrocławia, organizowanych m.in. przez gminę żydowską, jest Festiwal Kultu-

7 Edyta Stein - święta Kościoła katolickiego żydowskiego pochodzenia.

8 Ludwik Hirszfeld - lekarz, utworzył we Wrocławiu Instytut Immunologii i Terapii Doświadczalnej PAN.

9 Rodzina Wertheim - właściciele domu towarowego „Wertheim”, obecnie „Renoma".

10 Arthur i Georg Barasch - właściciele domów towarowych, z których najbardziej znany był obecny dom towarowy „Feniks”. 
ry Żydowskiej Simcha. Te młode osoby, które słyszały o nim bądź w nim uczestniczyły, kojarzyły go m.in. z odbywającymi się wówczas koncertami, warsztatami i wykładami, które uznały za bardzo potrzebne mieszkańcom, doceniając, że przybliżają kulturę żydowską, pomagają łamać stereotypy i uczą szacunku do inności. Wiele osób przyznało jednak, że nie słyszało o festiwalu, oceniając, że nie jest on wystarczająco „nagłośniony” i nie spotkały się z reklamującymi go plakatami. Niektórzy podkreślali wręcz, że nie są zainteresowani tego typu wydarzeniami i według nich mało ludzi w ogóle się nimi interesuje.

Ciekawie kształtowały się opinie respondentów na temat liczebności Żydów we Wrocławiu i w Polsce. W obu przypadkach zdecydowanie ją zawyżano, w odniesieniu do Wrocławia podając liczby od 1 do 20 tys., w skali całego kraju od 5 tys. nawet do miliona. Takie przeszacowywanie liczby Żydów może mieć kilka przyczyn. Jak zauważyła Datner (2010), może być reakcją na obecność w przestrzeni publicznej różnych „wątków żydowskich” (zainteresowanie historią i kulturą Żydów, liczne festiwale itd.), ale może być też efektem postaw niechętnych Żydom. Bilewicz (2008) zjawisko to powiązał z hipotezą kontaktu urojonego i antysemityzmem bez Żydów. Stwierdził, iż osoby, które mają tendencję do zawyżania liczby Żydów, żyją w świecie wyobrażonego kontaktu, myślą, że miały z nimi styczność. Spośród grupy respondentów tylko sześć osób, które uczestniczyły w różnych działaniach gminy żydowskiej lub miały znajomych Żydów, a więc zgodnie z koncepcją Bilewicza miały kontakt z rzeczywistymi Żydami, potrafiło prawidłowo określić liczbę członków wrocławskiej gminy żydowskiej, wskazując, iż jest to ok. 300 osób, a w całym kraju ok. 10 tys. Żydów.

\section{Wiedza na temat kultury żydowskiej i jej źródła}

Na podstawie wywiadów można stwierdzić, że wiedza na temat kultury żydowskiej w większości przypadków była zdecydowanie powierzchowna i oparta na wyobrażeniach i stereotypach. Rozmówcy najczęściej operowali hasłami - nazwami najbardziej znanych świąt (Pesach, Chanuka, Szabat), obrzędów (obrzezanie, bar micwa), potraw uznanych przez nich za żydowskie, wspominali o macy, Torze czy oczekiwaniu na Mesjasza. Dwie osoby przypisały Żydom Ramadan, a jedna sugerowała, że judaizm wywodzi się z chrześcijaństwa. W niektórych wypowiedziach zauważyć można brak wiedzy na temat zwyczajów żydowskich z jednoczesnym przenoszeniem na tę kulturę własnych wzorów kulturowych, np. gdy zarzucano Żydom brak dba- 
łości o groby bliskich. Podczas wywiadów pojawiły się jednak również pojedyncze, zaskakująco szczegółowe wypowiedzi, np. na temat święta Sukkot, zasad koszerności, zwyczajów szabatowych czy pogrzebowych.

Wiedzę na temat Żydów i kultury żydowskiej czerpano głównie ze źródeł wtórnych, telewizji i Internetu. Wspominano m.in. o filmach dokumentalnych emitowanych na kanale „National Geographic”, ale też o amerykańskich serialach, tj. „Przyjaciele”, „Seks w wielkim mieście” czy „Nie ma to jak hotel”, w których miały pojawiać się „żydowskie wątki”. Kilkoro rozmówców jako źródło swojej wiedzy wskazało także książki, rodzinę i żydowskich znajomych. Wiadomości dotyczące świąt czy Tory miały być przekazywane na lekcjach religii, kilka osób wspomniało również o lekcjach historii jako źródle wiedzy na temat Żydów, jednak bardzo fragmentarycznej, głównie w odniesieniu do Holokaustu i przy zupełnym pominięciu historii lokalnych społeczności żydowskich (por. Widawska, 2012). Jest to zastanawiające, biorąc pod uwagę fakt, że wrocławskie szkoły od wielu lat mają możliwość uczestniczenia w międzykulturowych i międzywyznaniowych działaniach Dzielnicy Wzajemnego Szacunku (Sanecka, 2017; Jasińska, 2010).

W przypadku osób, które posiadały bardziej szczegółową wiedzę na badany temat, można mówić o samodzielnym, świadomym i selektywnym jej poszukiwaniu, np. przez udział w międzykulturowych warsztatach dialogu Dzielnicy Czterech Wyznań, w Festiwalu Kultury Żydowskiej czy wykładach odbywających się w gminie żydowskiej. Wiele osób twierdziło jednak, że nie dysponuje odpowiednią wiedzą i nie uczestniczy w żadnych wydarzeniach, ponieważ nie są one odpowiednio rozreklamowane, a sami Żydzi, według nich, „nie biorą jakiegoś czynnego udziału w życiu Wrocławia” (31). Jak stwierdziła respondentka, taki brak zainteresowania świadczy o ignorancji, „patrzymy daleko, a nie na to, co mamy pod nosem”, ,jesteśmy ciekawi innych krajów i regionów, a nie jesteśmy zainteresowani tym, co dzieje się ulicę dalej” (21). Podobnie podsumowała inna z osób, stwierdzając, że „największym problemem nie jest brak tolerancji wobec mniejszości czy religii, ale brak chęci ich poznania, nawet jeśli jesteśmy świadomi ich obecności, nie jesteśmy nimi zainteresowani”(9), zamykamy się we własnym świecie.

\section{Stereotypy a postrzeganie Żydów wrocławskich}

Jak wynika z wywiadów, wiedzę na temat tej konkretnej, lokalnej społeczności część rozmówców zastępowała więc utrwalonymi w przeszłości wyobrażeniami i stereotypami na temat Żydów (por. Bystroń, 1995; Cała, 2005; 
Tokarska-Bakir, 2008; Jeziorski, 2009). Korzystając ze znanych klisz, przypisywała wrocławskim Żydom czarne, długie stroje, jarmułki, czarne lub rude włosy i pejsy, a także takie cechy charakteru, jak: oszczędność, przedsiębiorczość, inteligencję czy chytrość. Nazywała ich „królami handlu”, bankierami, lichwiarzami i podkreślała, że są bogaci. W dwóch wypowiedziach pojawił się również element stereotypu spiskowego, oskarżenie o zło i wykorzystywanie innych narodów: „Są odpowiedzialni za wszystkie spiski, rządzą światem, mają całe pieniądze świata w kieszeni” (M39). Kilku respondentów podkreśliło też ich odmienność religijną. Żydom wrocławskim przypisywano więc zarówno pozytywne, jak i negatywne cechy, powielane z tradycyjnego stereotypu. Ich wybór wydaje się jednak dość ograniczony, nie pojawiły się też odwołania do przesądów, np. wiary w mord rytualny, co może wynikać z faktu, iż rozmówcami byli młodzi ludzie, nieobciążeni w tak dużym stopniu negatywnymi skojarzeniami. Tradycyjny wizerunek uzupełniany był opiniami na temat konfliktu izraelsko-palestyńskiego lub relacji polsko-izraelskich (spór wokół ustawy o Instytucie Pamięci Narodowej).

Stereotyp, którym operowała część rozmówców w odniesieniu do miejscowej społeczności, był więc uboższy, ale zbieżny z tradycyjnym obrazem Żydów. Podobny wizerunek wyłonił się również z badań CBOS w 2015 r. na grupie dorosłych Polaków (Roguska, 2015). Odmienne wyniki uzyskano jednak podczas badań wśród młodzieży ponadgimnazjalnej na przełomie 2008 i 2009 r. Na ich podstawie M. Bilewicz zauważył, że: „wśród młodzieży dominuje wizerunek Żydów jako odmiennych (kulturowo, religijnie), natomiast bardzo rzadkie są stereotypowe wyobrażenia z przeszłości (handlarz, zaradny, broda, pejsy)" (Ambrosewicz-Jacobs, 2014, s. 2).

Mimo iż część rozmówców postrzegała Żydów wrocławskich stereotypowo, większość podkreślała jednak, że nie odróżniają się od pozostałych mieszkańców miasta i są tacy sami jak wszyscy. Takie osoby zdecydowanie wyrażały też swój dystans wobec znanych im stereotypów, twierdząc, iż mają świadomość, że nie mają one wiele wspólnego z prawdą.

\section{Stosunek respondentów do przedmiotu badań}

Warto podkreślić, że niektórzy respondenci po zakończeniu wywiadu prosili o wyjaśnienie nieznanych im kwestii. Przyznawali, że jest im wstyd z powodu niewiedzy, i deklarowali większe zainteresowanie wrocławskimi Żydami. Jeden z takich respondentów, spotkany w klubokawiarni dzielącej dziedziniec z synagogą, który przyznał, że nie wie, gdzie synagoga się znajduje, za- 
raz po rozmowie wziął udział w jej zwiedzaniu. Zaopatrzył się tam również w czasopismo „Chidusz”, które obiecał przeczytać. Pojawiły się także osoby nastawione niechętnie do Żydów, jak mężczyzna, który wyrażając się o nich pogardliwie, twierdził, że nie spotkał się z antysemityzmem, ale jest „na okrągło świadkiem filosemityzmu w mediach" (39). Większość respondentów odnosiła się jednak do Żydów z wyraźną sympatią (39 osób) i negatywnie oceniała akty antysemityzmu. Najczęściej wspominano spalenie kukły Żyda na wrocławskim rynku, ale wskazywano też na bezrefleksyjne stwierdzenia typu „nie bądź Żydem” czy opowiadanie niestosownych żartów na ich temat. Trzy osoby przyznały, że z uprzedzeniami wobec Żydów spotkały się w swoich domach lub wśród znajomych, same dystansowały się jednak wobec nich. Antysemityzm uznawały za niezrozumiałe zachowanie, przejaw nieświadomości i głupoty. I jak podkreśliła jedna z respondentek, takie postawy pojawiają się mimo tego, że większość ludzi nigdy nie widziała Żyda. Wniosek ten znajduje potwierdzenie w wynikach Polskiego Sondażu Uprzedzeń 2, podczas którego zauważono, że 80\% Polaków nie zna żadnego Żyda, a brak szans na zaistnienie kontaktu międzygrupowego, ze względu na małą populację grupy, sprzyja utrzymywaniu się postaw niechętnych (Stefaniak, Witkowska, 2015).

\section{Podsumowanie}

Choć można odnieść wrażenie, że młodzi mieszkańcy miasta dość dobrze orientują się w historii i współczesności Żydów wrocławskich oraz specyfice kultury żydowskiej, to należy podkreślić, że zrekonstruowana podczas badań wiedza stanowi sumę wszystkich zebranych wypowiedzi. Wśród rozmówców były zarówno osoby nieposiadające niemal żadnej wiedzy na temat Żydów wrocławskich, którzy byli dla nich abstrakcyjnymi bytami, jak i takie, które z racji wykształcenia, zainteresowań czy posiadania żydowskich znajomych dysponowały bardziej szczegółowymi informacjami. Dominowali jednak respondenci, których wiedza była zdecydowanie fragmentaryczna, powierzchowna, hasłowa, a także w dużej mierze oparta na domysłach, stereotypach i wyobrażeniach. Jak wykazały badania, bliskość przestrzenna, a więc sam fakt zamieszkiwania w pobliżu gminy żydowskiej czy na terenie Dzielnicy Czterech Wyznań lub pracy w miejscach z nimi związanych, tj. w Ciż Cafe czy Centrum Informacji Turystycznej, nie była gwarantem posiadania głębszej wiedzy na temat wrocławskich Żydów i żydowskich miejsc, a także uczestniczenia w różnych wydarzeniach. Podobnie fakt zamieszkiwania w mieście od urodzenia niekoniecznie oznaczał, że rozmówcy potrafili od- 
naleźć i umiejscowić „żydowskość” we Wrocławiu. Zdarzało się, że większą wiedzą dysponowały osoby mieszkające w mieście zaledwie kilka lat, ale bardziej zainteresowane wydarzeniami kulturalnymi i edukacyjnymi. To z jednej strony wydaje się efektem braku odpowiedniej edukacji międzykulturowej i regionalnej, ale w dużym stopniu także skutkiem powojennej wymiany ludności, która doprowadziła do zerwania ciągłości kulturowej. Jak pisze Ziątkowski (2000, s. 5): „Warszawiacy, krakowianie, czy berlińczycy doskonale wiedzą, że w danym budynku przed wojną mieszkał rabin, w innym zaś gmachu mieścił się żydowski dom starców. We Wrocławiu natomiast owe miejsca pozostają bezimienne, zapomniane, znane być może grupce specjalistów lub miłośników historii”. To cecha, która wyróżniać ma Wrocław na tle innych europejskich miast przez wieki zasiedlanych przez ludność żydowską. Również badania CBOS potwierdzają, że mieszkańcy miast południowo-zachodniej Polski rzadziej deklarują świadomość tego, że w ich miejscowościach przed wojną mieszkali Żydzi. Odsetek takich osób był najniższy w Polsce i wynosił 35\% (Roguska, 2015).

\section{Bibliografia}

Ambrosewicz-Jacobs, J. 2014. Młodzież wobec Żydów i Holokaustu. https:// www.nigdywiecej.org/pdf/pl/pismo/21/mlodziez_wobec_zydow_i_holokaustu.pdf (29.01.2020).

Ambrosewicz-Jacobs, J. 2005. Postawy młodzieży polskiej wobec Holokaustu - badania z lat 1997-2000. W: Ambrosewicz-Jacobs, J. i Hońdo, L. red. Dlaczego należy uczyć o Holokauście. Kraków: UJ, ss. 103-113.

Banasiewicz-Ossowska, E. 2015. Życie religijne i jego organizacja w gminie żydowskiej we Wrocławiu. Roczniki Teologiczne. 62 (9), ss. 173-190.

Bartmiński, J. 1995. Nasi sąsiedzi w oczach studentów. W: Walas, T. red. Narody i stereotypy. Kraków: Międzynarodowe Centrum Kultury, ss. 258-269 .

Bilewicz, M. 2008. Czy kontakt z Żydami zmniejsza antysemityzm? Hipoteza kontaktu urojonego. W: Żyndul, J. red. Różni razem. Młodzi polscy naukowcy o Żydach. Warszawa: UW, ss. 249-257.

Bilewicz, M. i Wójcik, A. 2009. Antysemityzm na gruzach sztetl. Stosunek polskiej młodzieży do Żydów w miastach i miasteczkach południowej i wschodniej Polski. W: Nijakowski, L. red. Etniczność, pamięć, asymilacja. Wokót problemów zachowania tożsamości mniejszości narodowych $i$ etnicznych w Polsce. Warszawa: Wydawnictwo Sejmowe, ss. 153-167. 
Bystroń, J. St. 1995. Megalomania narodowa. Warszawa: Książka i Wiedza. Cała, A. 2005. Wizerunek Żyda w polskiej kulturze ludowej. Warszawa: Oficyna Naukowa.

Datner, H. 2010. Obraz współczesnej społeczności żydowskiej. W: Zieliński, P. red. Konferencja. Mniejszość żydowska w Polsce - mity i rzeczywistość. Warszawa: Wydawnictwo Sejmowe, ss. 45-46.

Jasińska, M. 2010. Wrocławska Dzielnica Wzajemnego Szacunku Czterech Wyznań. W: Kusek, R. i Sanetra-Szeliga, J. red. W stronę nowej wielokulturowości. Kraków: Międzynarodowe Centrum Kultury, ss. 188-197.

Jeziorski, I. 2009. Od obcości do symulakrum. Obraz Żyda w Polsce w XX wieku. Antropologiczne studium przypadku. Kraków: Nomos.

Kichler, J. 2015. Dzielnica Wzajemnego Szacunku Czterech Wyznań. W: Lisek, J. i Szajda, M. red. Jerzy Kichler. Odrodzenie życia żydowskiego we Wrocławiu. Człowiek dialogu. Wrocław: Fundacja Dzielnicy Wzajemnego Szacunku Czterech Wyznań, ss. 59-62.

Łukaszewicz, Ł. 1983. Stereotyp Żyda u studentów. Znak. 35 (2-3), ss. 453-462 .

Roguska, B. 2015. Postrzeganie Żydów i stosunków polsko-żydowskich. CBOS. Komunikat $z$ badań. https://cbos.pl/SPISKOM.POL/2015/K_112_15.PDF (29.02.2020).

Sanecka, A. 2017. Dzielnica Wzajemnego Szacunku Czterech Wyznań i realizowane w niej programy dydaktyczne oraz ich edukacyjny potencjał. W: Humeniuk, M. i Paszenda, I. red. Między ekskluzja a inkluzja w edukacji religijnej. Wrocław: UW, ss. 265-275.

Stefaniak, A. i Witkowska, M. 2015. Społeczne kontakty Polaków, czyli czy znamy ludzi innych niż my sami i czy chcemy ich poznawać? W: Stefaniak, A., Bilewicz, M. i Winiewski, M. red. Uprzedzenia w Polsce. Warszawa: Wydawnictwo Stowarzyszenia Filomatów, Wydawnictwo Liberi Libri, ss. $105-130$.

Szaynok, B. 2006. Żydowskie nowe życie we Wrocławiu i na Dolnym Śląsku. W: Żuk, P. i Pluta, J. red. My Wrocławianie. Społeczna przestrzeń miasta. Wrocław: Wydawnictwo Dolnośląskie, ss. 135-150.

Szymański, C.K. 2012. Postrzeganie Żydów przez młodych Polaków na przykładzie częstochowskiej młodzieży maturalnej. https://czestochowajews. org/wp-content/uploads/szymanski_pol.pdf, (5.02.2020).

Tokarska-Bakir, J. 2008. Legendy o krwi. Antropologia przesqdu. Warszawa:

Wydawnictwo W.A.B.

Waszkiewicz, E. 2010. Żydzi w Polsce wczoraj i dziś na przykładzie Dolnego 
Śląska. W: Zieliński, P. red. Konferencja. Mniejszość żydowska w Polscemity i rzeczywistość. Warszawa: Wydawnictwo Sejmowe, ss. 35-44.

Widawska, E. 2012. Edukacja międzykulturowa w odniesieniu do mniejszości narodowych, na przyktadzie mniejszości żydowskiej. https://czestochowajews.org/wp-content/uploads/widawska_pol.pdf (7.02.2020).

Włodarczyk, T. i Kichler, J. 2016. Przewodnik po żydowskim Wrocławiu. Wrocław: Towarzystwo Społeczno-Kulturalne Żydów w Polsce.

Wójcik, A. 2008. Historia stosunków polsko-żydowskich w oczach polskiej młodzieży. W: Żyndul, J. red. Różni razem. Młodzi polscy naukowcy o Żydach. Warszawa: UW, ss. 258-267.

Zabłocka-Kos, A. 2008. W poszukiwaniu nowych idei. „Dzielnica żydowska” we Wrocławiu - przeszłość i teraźniejszość. https://bon.edu.pl/media/ book/pdf/W_poszukiwaniu_nowych_idei-AZK.pdf (29.02.2020). Ziątkowski, L. 2000. Dzieje Żydów we Wrocławiu. Wrocław: Wydawnictwo Dolnośląskie.

\title{
Jews from Wrocław in the consciousness of young inhabitants of Wroclaw - the knowledge and stereotypes
}

\begin{abstract}
The article discusses the preliminary conclusions of the ethnographic research, carried out in Wrocław at the turn of June and July 2019, regarding the perception of Wrocław Jews by young city residents. The research was aimed at verifying the state of knowledge about the history of Jews in Wrocław, their contemporary social, cultural and religious activities as well as the Jewish culture itself. An important aspect was to check how this community functions in the minds of young city residents, what is the impact of stereotypes on its perception, and what are the sources of knowledge about it. It was also important to determine which places in space are identified as Jewish and to find out if young residents of Wrocław participate in events organized by the Jewish community, how they evaluate them and whether they consider them necessary.
\end{abstract}

Keywords: Jews in Wrocław, Jewish culture, The Four Denominations District, stereotype of a Jew, ethnographic research, intercultural education 